\title{
SEISMIC STRENGTHENING OF EXISTING REINFORCED CONCRETE BUILDINGS IN JAPAN
}

\section{Shunsuke Sugano*}

1.

INTRODUCTION

A number of reinforced concrete buildings, damaged by recent severe earthquakes, required extensive repair and also strengthening $(1-4)$. The Tokachi-oki Earthquake of 1968 heavily damaged a large number of low rise buildings. Some of these were strengthened by the addition of structural walls. These buildings are still in use. Because of the lack of guidelines, the design as well as the construction for strengthening was based on engineering judgement alone. The destructive 1978 Miyagikenoki Earthquake was also followed by the strengthening of a number of buildings. However, in this case materials and techniques for construction were specifically selected and the design was based on experimental or analytical investigations or on guidelines, where these were available.

These studies have also indicated that there is a wide scatter in the level of seismic resistance of existing buildings. It was found that a considerable number of low to medium rise buildings, designed and constructed in accordance with previous building codes, may need strengthening (16). Consequently a number of public and private buildings, considered hazardous, were strengthened or rebuilt.

It is intended to provide not only increased strength, so as to prevent collapse, but also increased stiffness to give increased protection against damage to non-structural building components. To establish guidelines for design and construction, several experimental studies, relevant to the seismic strengthening of
existing structures, have been conducted $7,9,17)$. However, test data, accumulated over some 8 years, have not been systematically reviewed as yet.

The necessity for strengthening of hazardous buildings was recognised for some time, and as a consequence an advisory committee for the Japanese Ministry of Construction prepared design guidelines in 1977(12). These design guidelines were intended to be used in conjunction with the method of evaluation of seismic safety of existing buildings, proposed by the same committee. This method has been described in some detail in New Zealand(13). In a number of cases these guidelines have already been used in Japan.

This paper describes techniques whereby current knowledge developed in Japan can be used to give increased resistance to existing substandard buildings. First the general design procedure is described and then brief reviews of some of the relevant experimental studies are given. Some application of strengthening techniques to existing buildings will also be described.
2 .

2.1

DESIGN AND CONSTRUCTION

The approach to the design and construction for the strengthening of hazardous buildings in Japan is summarized in the flow chart of Fig. 1. Detailed discussions are held before the design commences and the construction technique is chosen. The results of the seismic evaluation and in certain cases also those of field investigations are required. Laboratory tests may be necessary to provide additional information for design and construction. provide:

The aims of the strengthening are to

Increased strength with respect to lateral loading, or

Increased ductility or

A proper combination of these two features.

These concepts are illustrated in Fig. 2. The combination of strength and ductility involve the proper balance between strength and stiffness.

To provide increased strength is considered as being the most promising approach in the strengthening of low to medium rise buildings. Even if ductility is provided, increased strength is expected to reduce the magnitudes of inelastic displacements. For ductile structures it is considered to be particularly important to reduce eccentricities resulting often from the irregular distribution of stiffness within a storey or throughout the entire structure.

\subsection{Construction Techniques}

Examples of construction techniques to meet both, the increased strength and increased ductility, criteria for strengthening are given in Fig. 3. Generally new elements may be added to existing structures to give increased strength, or existing framing elements may be reinforced with new materials to improve their ductility. Typical strengthening methods considered in Japan are assembled in the chart of Fig. 4. Infilled walls and wing walls, extensively used in Japan and shown in Figs. $3(a)$ and (b), are cast in situ or precast wall elements which are attached to frames or to columns, as appropriate.

For the systems shown in Fig. 3(a), (b) and (d), cast in situ or precast concrete is commonly used with the various connection techniques that are listed in Fig. 4. Typical details for such connections are given in Figs. 5 and 6 where additional information required in the design is also given. Careful attention must be paid to connections, because they 


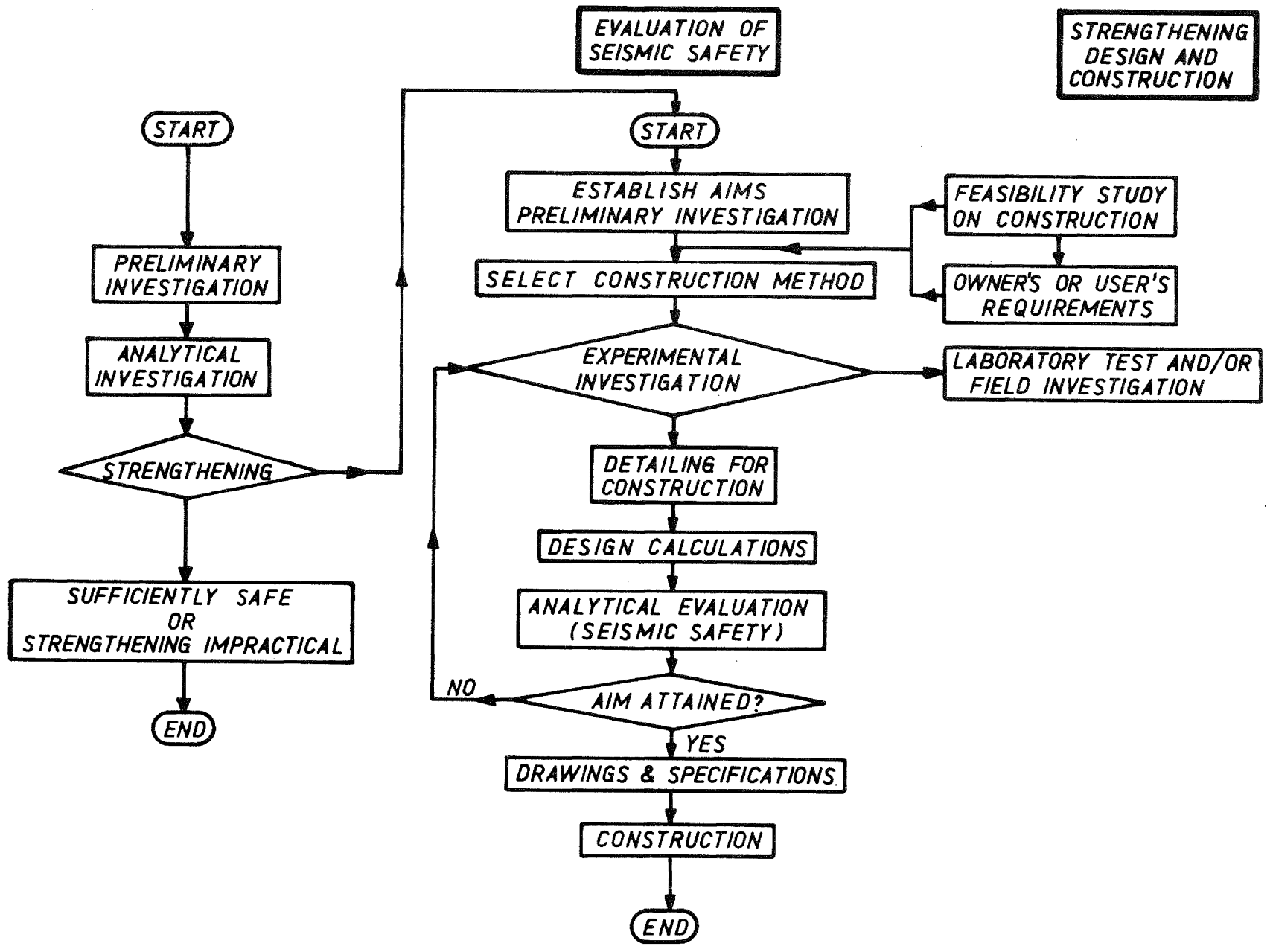

FIG. 1 - FLOW CHART OF DESIGN AND CONSTRUCTION OF SEISMIC STRENGTHENING
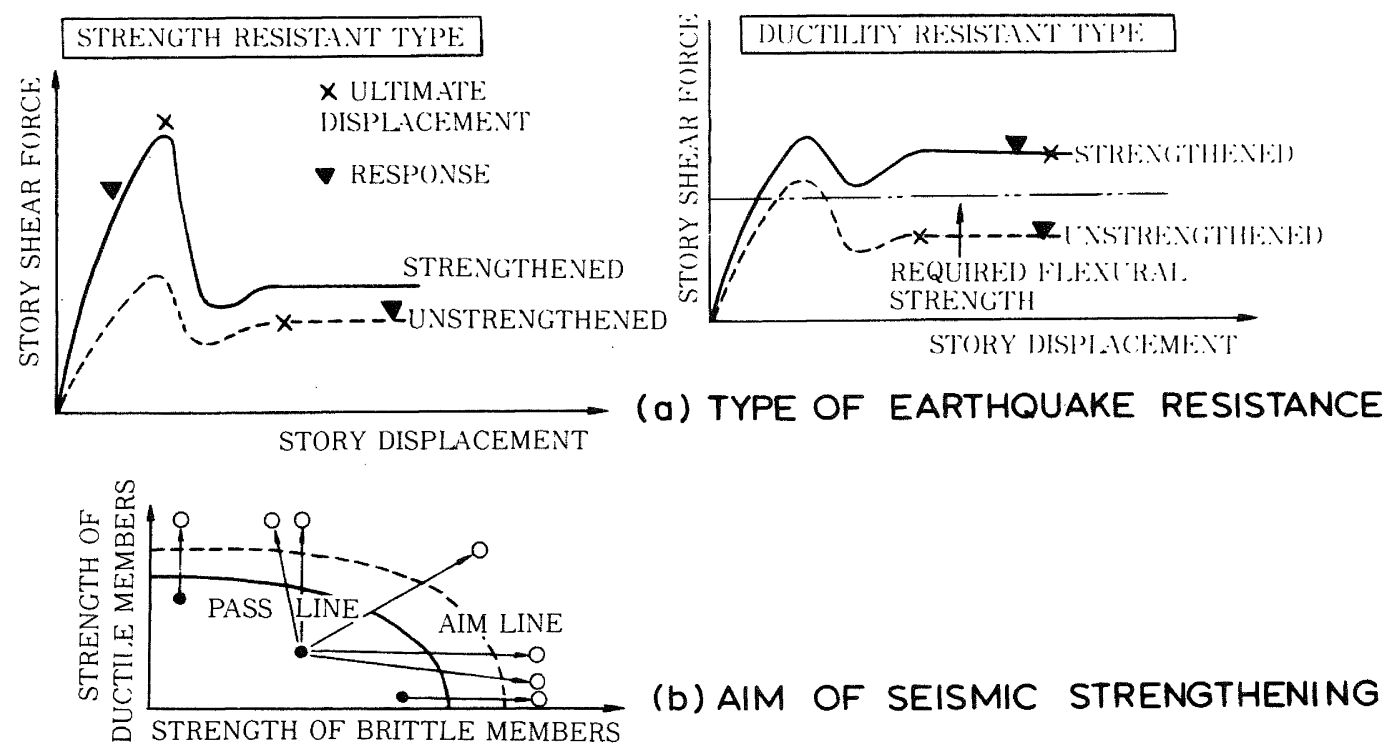

(b) AIM OF SEISMIC STRENGTHENING 
will strongly affect the behaviour of the strengthened structure, as well as for the placing of concrete on the site. High pressure pumping of the fresh concrete may be necessary to avoid the formation of cavities between the new and the existing elements. Detailing of bracing elements should be such as to avoid stress concentrations.

In the process of increasing the ductility of existing columns, such as shown in Fig. 3(e), (f) and (g), one of the aims is to increase their shear strength. This is achieved by the wrapping techniques shown in these illustrations. A narrow gap at the ends of the encasement is provided to avoid the undesired increase of the flexural strength of the member at that section.

\subsection{Design Procedure}

The safety of the strengthened building is assessed with the recently introduced Japanese evaluation procedure for existing reinforced concrete buildings, reported in detail by Aoyama(13). If they are more detailed, other procedures are also permissible. The guideline(12) gives specific calculation techniques for infilled walls, wing walls and encased columns. These calculation procedures are based on tests.
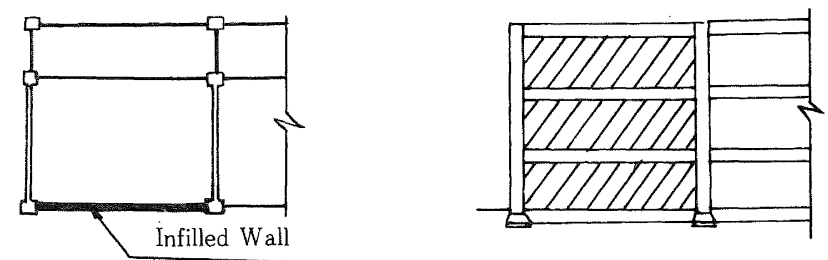

a) BY INFILLED WALLS
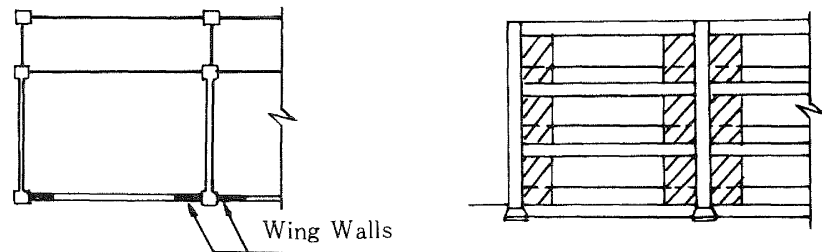

b) BY WING WALLS
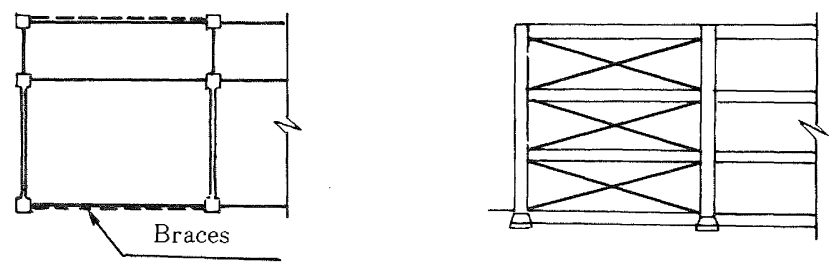

c) BY BRACES

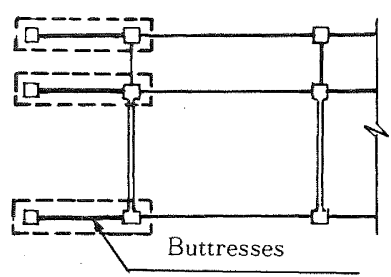

d) BY BUTTRESSES
As an example, the design strength of an infilled wall assembly of Fig. $5(d)$ is given as the smaller of either:

The total shear strength of the wall panel and both columns, treated as independent elements or

The total shear strength of one column and the connection to the wall along the beam and the punching (sliding) shear strength of the other column.

These procedures assume that failure will occur either in the wall panel or along the connections where shear is being introduced to the infill wall. The strength of the connections is evaluated either from theoretical considerations or from empirical equations applicable to the techniques shown in Fig. 5 (a) to (c). The punching or sliding shear strength of the column is given in terms of the principal tensile stress in the concrete.

The contribution to flexural and shear strength by a column strengthened by wing walls, as shown in Fig. 6(a), is estimated to be $80 \%$ of that of a column with identical properties but cast monolithically with the wing walls. In the case of wing walls with dowel connections, an

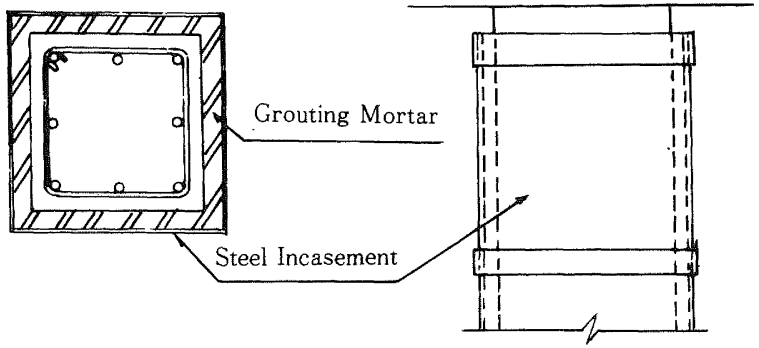

e) BY STEEL INCASEMENT

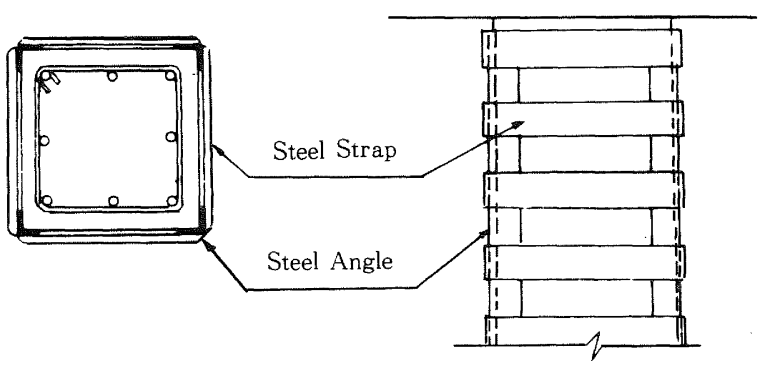

f) BY STEEL STRAPS AND ANGLES

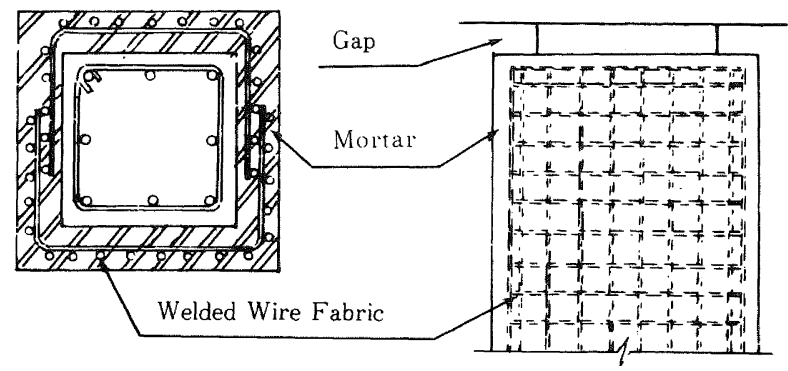

g) BY WELDED WIRE FABRICS 


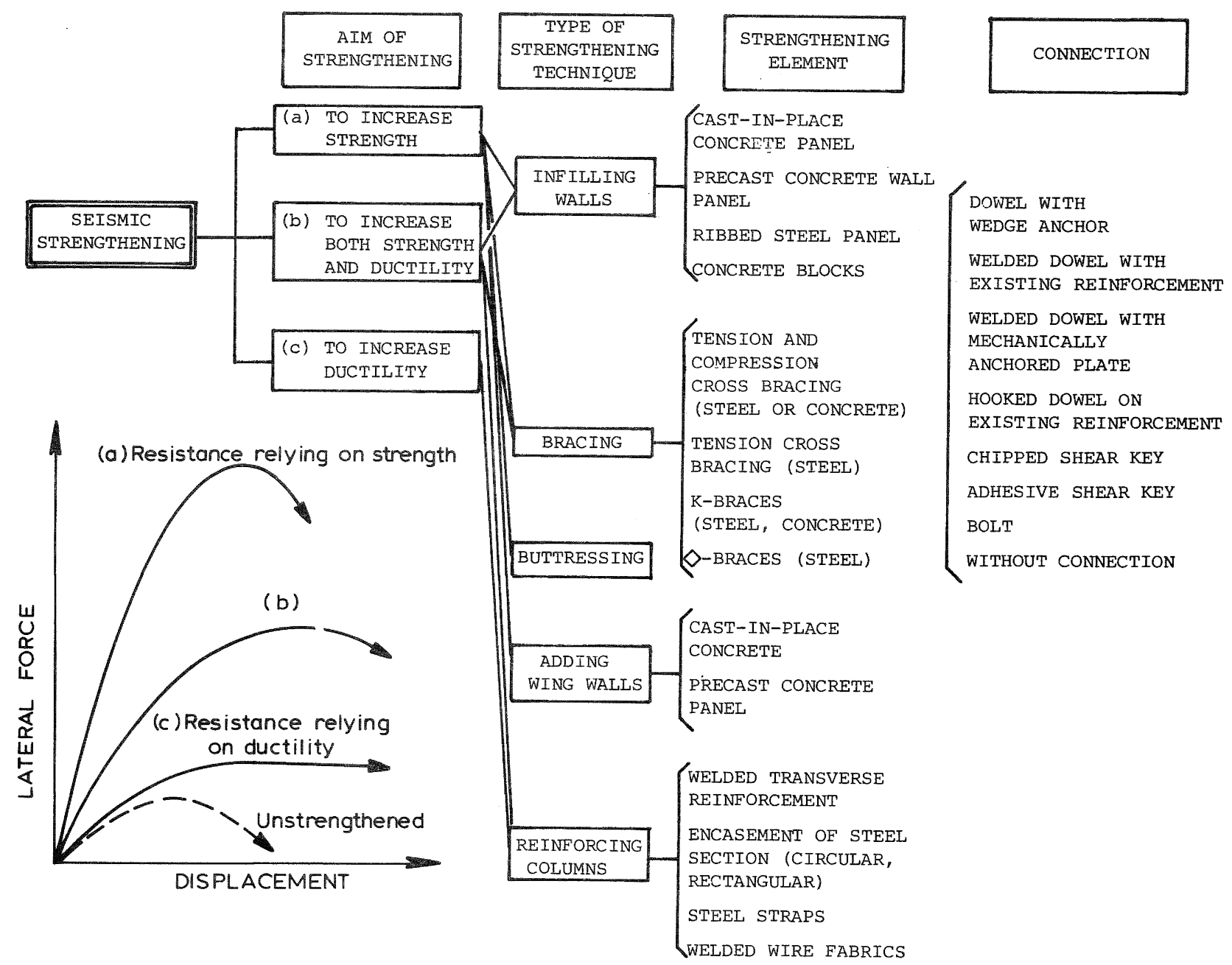

FIG. 4 - TYPICAL STRENGTHENING METHODS

idealized truss system is used to model load transfer, as shown in Fig. $6(\mathrm{C})$.

In the case of encased columns of the type shown in Fig. $3(\mathrm{e})$, (f) and (g), the shear and flexural strength is evaluated as for ordinary monolithic reinforced concrete columns, using the increased dimensions as well as the contribution of the added steel elements.

For other strengthening methods, evaluation by testing is recommended.

\subsection{Selection of Construction Methods}

The selection of construction methods should be based on the overall considerations of the work involved on the site, weights and conveyance of elements to be handled, cost and also on the structural characteristics relevant to each alternative of structural solution? Table I illustrates these aspects. It is based on the author's experimental study of one-bay, one-storey simple frames which were strengthened by five different techniques (8). The quantities in brackets in the table represent normalised values in terms of the infilled concrete wall construction which was taken as unity.

For this type of structure it was found, as Table I indicates, that reinforced concrete construction has merits in terms of cost, strength and stiffness while it is penalized for site work and conveyance of components. In general steel bracing was found to offer advantages in conveyance, weight and ductility but it was the most expensive solution.

\section{RESEARCH}

The number of strengthened structures that have been examined experimentally served as a background in formulating the guidelines for design $(12)$.

The earliest tests were aiming at the improvement of ductility in columns $(5,9)$ by the techniques shown in Fig. 3, and at the boosting of the strength of frames by the addition of precast and cast in situ walls $(5,6,17)$. Subsequently one storey infilled frames with various connection were examined. Currently, three storey frames, strengthened by infilling and bracing, were also tested. In the following a brief review of the findings of some of these studies is given.

\subsection{Infilled Concrete Walls}

In a series of tests with three types of infilled walls it was found that: in strength. 


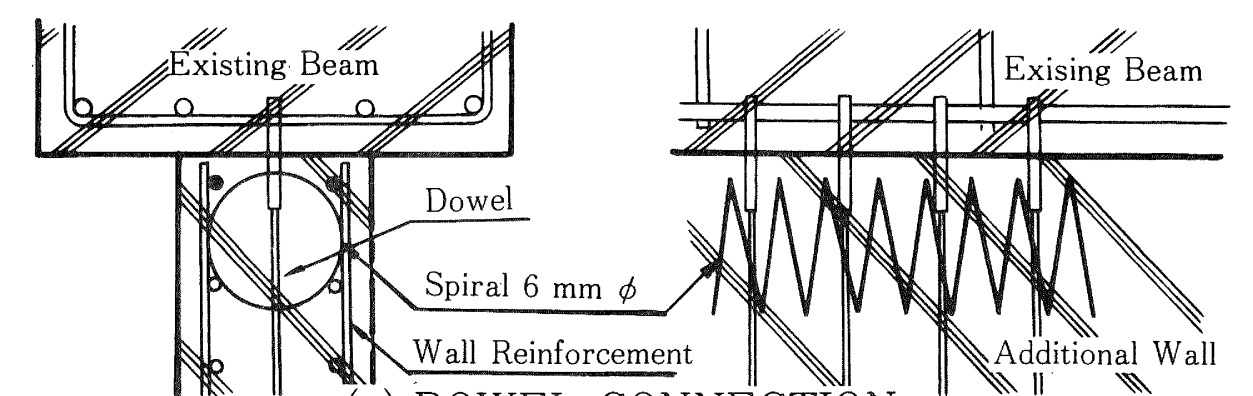

(a) DOWEL CONNECTION

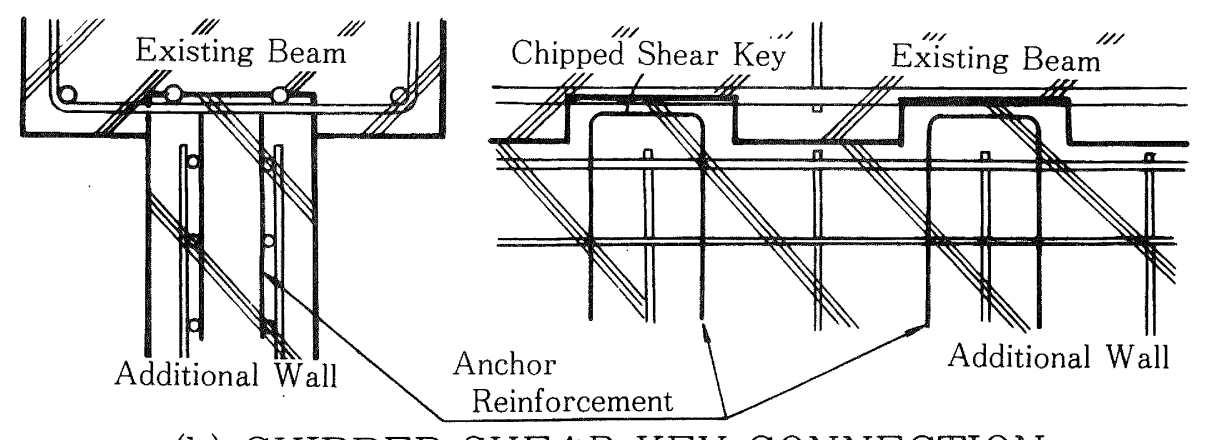

(b) CHIPPED SHEAR KEY CONNECTION

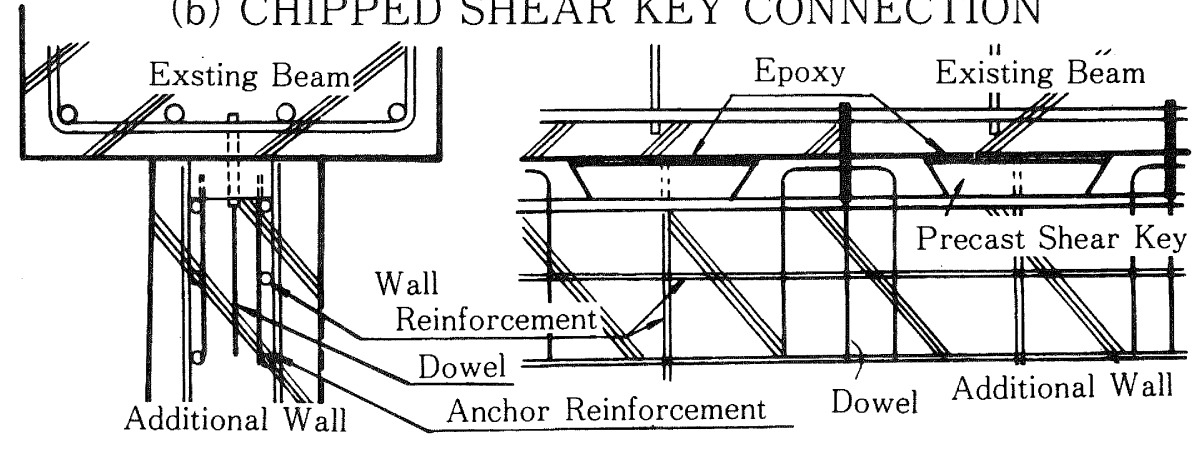

(c) PRECAST SHEAR KEY CONNECTION

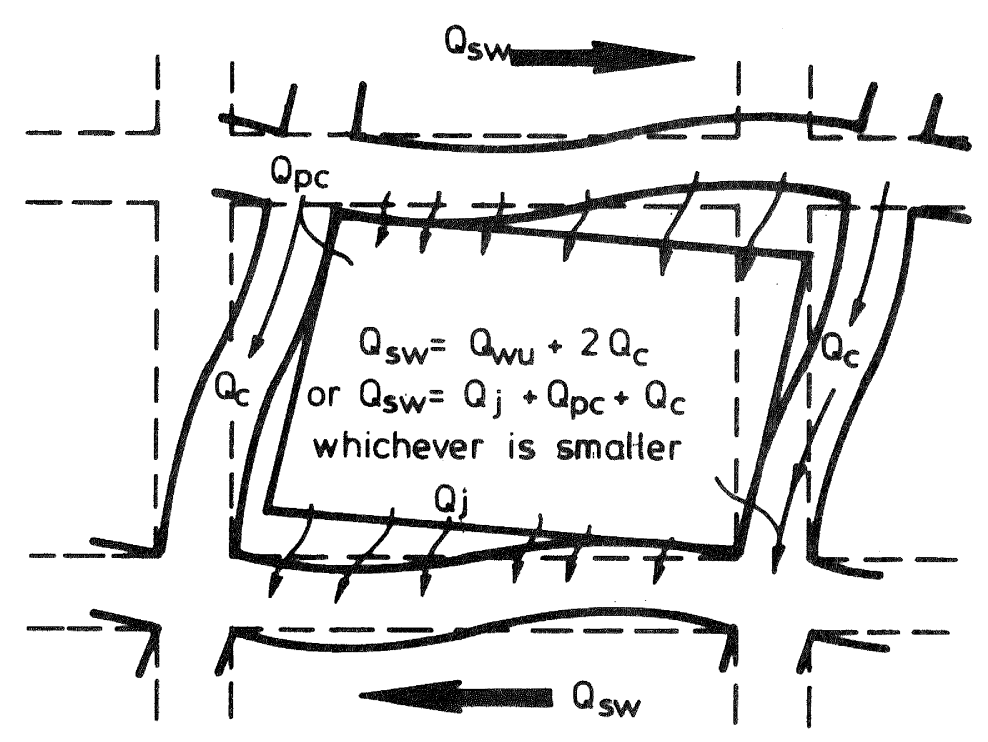

$Q_{w u}=$ Shear strength of wall panel

$Q_{\text {sw }}=$ Strength of an infilled wall

$a_{p c}=$ Punching shear strength at top of column

$Q_{j}=$ Total strength of connections along a beam

$a_{c}=$ Strength of a column

(d) DESIGN OF INFILLED WALL

FIG. 5 - DESIGN AND CONSTRUCTION OF INFILLED WALLS (12) 


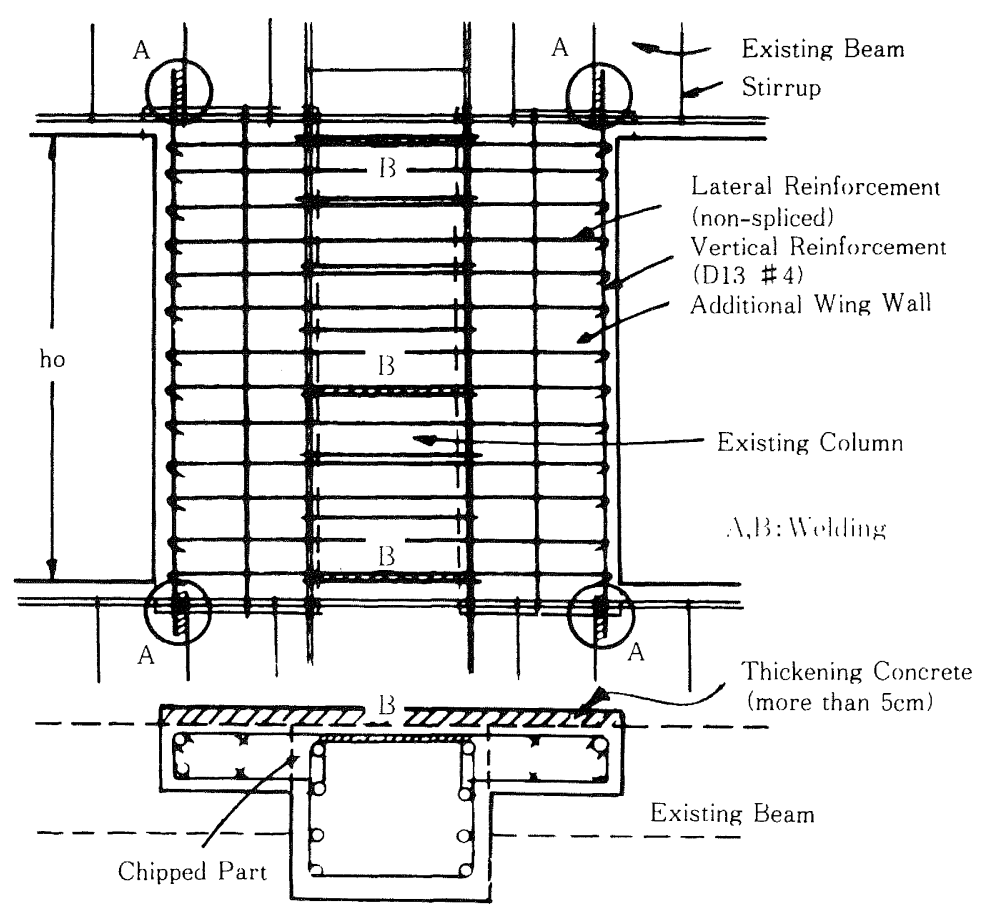

(a) MONOLITHICALLY CAST WING WALLS

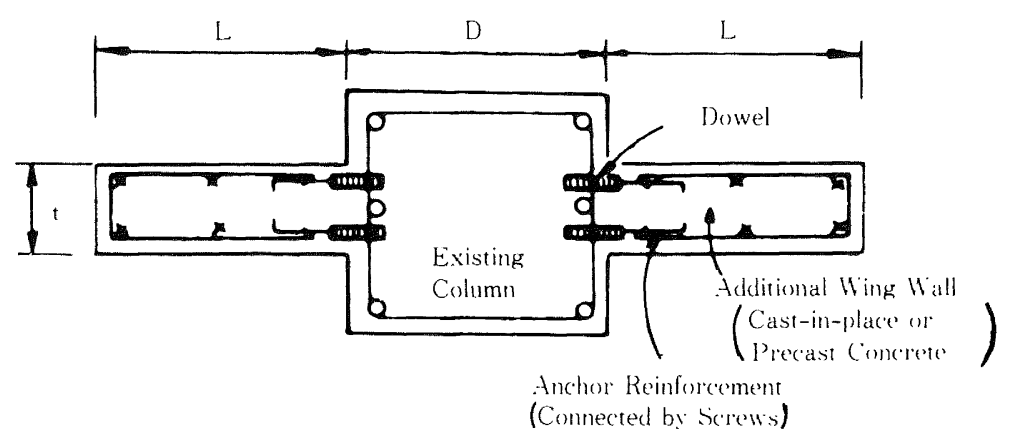

(b) WING WALLS WITH DOWEL CONNECTIONS

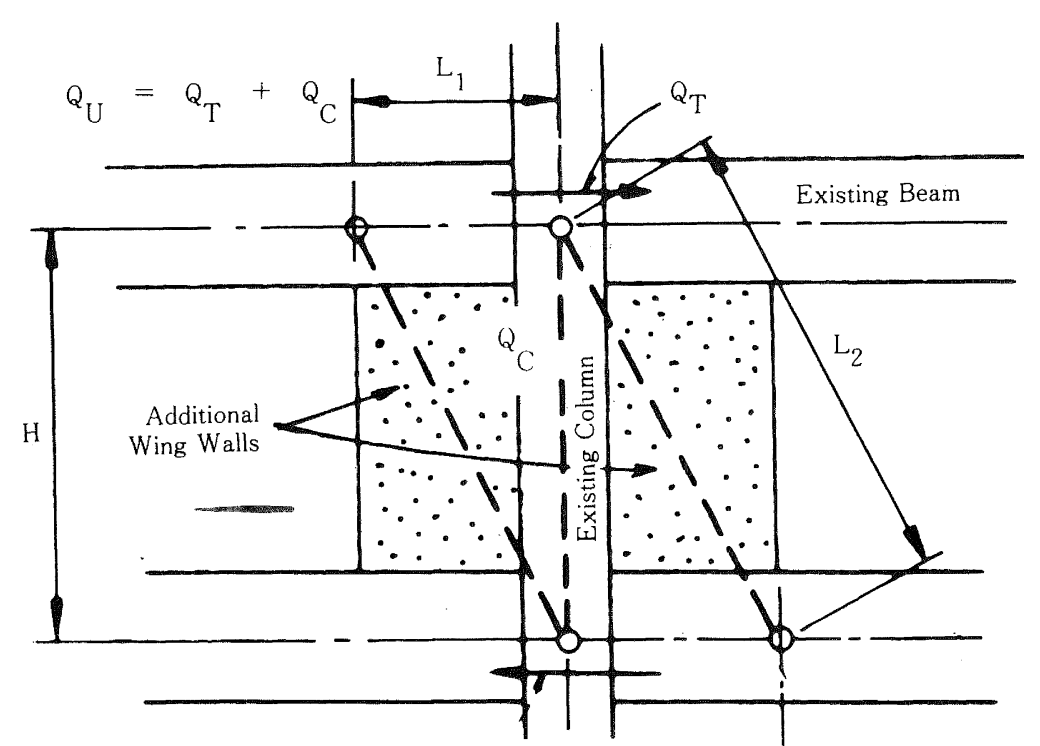

(c) DESIGN OF WING WALLS WITH DOWEL CONNECTION

FIG. 6 - DESIGN AND CONSTRUCTION OF WING WALLS (12) 
TABLE I - FEASIBILIBY STUDY OF STRENGTHENED ONE-STOREY FRAMES

\begin{tabular}{|c|c|c|c|c|c|c|c|c|}
\hline & \multicolumn{4}{|c|}{ Construction } & \multirow{2}{*}{$\begin{array}{l}\text { Cost of } \\
\text { Structures }\end{array}$} & \multicolumn{3}{|c|}{ Structural Capacity } \\
\hline & Workability & Conveyance & Curing & Weight & & Stiffness & Strength & Ductility \\
\hline $\begin{array}{l}\text { Infilled } \\
\text { Concrete } \\
\text { Wall }\end{array}$ & $\begin{array}{l}\text { much work } \\
\text { necessary }\end{array}$ & $\begin{array}{l}\text { difficult } \\
\text { conveyance } \\
\text { of concrete }\end{array}$ & necessary & $\begin{array}{l}\text { heavy } \\
(1.00)\end{array}$ & $\begin{array}{l}\text { cheap } \\
(1.00)\end{array}$ & $\begin{array}{l}\text { high } \\
(1.00)\end{array}$ & $\begin{array}{l}\text { high } \\
(1.00)\end{array}$ & $\begin{array}{l}\text { low } \\
(1.00)\end{array}$ \\
\hline $\begin{array}{l}\text { Infilled } \\
\text { Concrete } \\
\text { Block Wall }\end{array}$ & $\begin{array}{l}\text { easy work, } \\
\text { few workman }\end{array}$ & easy & $\begin{array}{l}\text { local } \\
\text { curing } \\
\text { necessary }\end{array}$ & $\begin{array}{l}\text { heavy } \\
(1.00)\end{array}$ & $\begin{array}{l}\text { slightly } \\
\text { expensive } \\
\quad(1.61)\end{array}$ & $\begin{array}{l}\text { low } \\
(0.30)\end{array}$ & $\begin{array}{l}10 \mathrm{~W} \\
(0.30)\end{array}$ & $\begin{array}{l}\text { low } \\
(1.13)\end{array}$ \\
\hline $\begin{array}{l}\text { Infilled } \\
\text { Steel } \\
\text { Wall }\end{array}$ & $\begin{array}{l}\text { easy work, } \\
\text { but accuracy } \\
\text { needed }\end{array}$ & easy & $\begin{array}{l}\text { local } \\
\text { curing } \\
\text { necessary }\end{array}$ & $\begin{array}{l}\text { light } \\
(0.39)\end{array}$ & $\begin{array}{c}\text { expensive } \\
(2.41)\end{array}$ & $\begin{array}{c}\text { moderate } \\
(0.49)\end{array}$ & $\begin{array}{c}\text { moderate } \\
(0.78)\end{array}$ & $\begin{array}{l}\text { low } \\
(0.96)\end{array}$ \\
\hline $\begin{array}{l}\text { Compres- } \\
\text { sion } \\
\text { Braces }\end{array}$ & $\begin{array}{l}\text { simple } \\
\text { connection, } \\
\text { easy work }\end{array}$ & easy & $\begin{array}{l}\text { local } \\
\text { curing } \\
\text { necessary }\end{array}$ & $\left|\begin{array}{l}\text { light } \\
(0.39)\end{array}\right|$ & $\mid \begin{array}{c}\text { slightly } \\
\text { expensive } \\
(1.47)\end{array}$ & $\begin{array}{l}\text { low } \\
(0.27)\end{array}$ & $\begin{array}{l}\text { low } \\
(0.63)\end{array}$ & $\begin{array}{l}\text { high } \\
(1.7)\end{array}$ \\
\hline $\begin{array}{l}\text { Tension } \\
\text { Braces }\end{array}$ & $\begin{array}{l}\text { easy work } \\
\text { but accuracy } \\
\text { needed }\end{array}$ & easy & $\begin{array}{l}\text { necessary } \\
\text { for chipped } \\
\text { slabs }\end{array}$ & $\mid \begin{array}{l}\text { light } \\
(0.44)\end{array}$ & $\begin{array}{c}\text { expensive } \\
(2.93)\end{array}$ & $\begin{array}{l}\text { low } \\
(0.24)\end{array}$ & $\begin{array}{l}\text { low } \\
(0.67)\end{array}$ & $\begin{array}{l}\text { high } \\
(1.7)\end{array}$ \\
\hline
\end{tabular}

(b) Dowels connecting wall to frames failed simultaneously at the threaded shank by shear.

(c) It was effective to provide gaps along columns to allow walls to behave in a ductile manner.

(d) Chipped shear keys provided as good a shear connection as monolithic construction.

When adequate connection, placed continuously around all boundary members, were provided, infill frames exhibited the same strength as monolithic walls with identical boundary elements. Recently tested multiple precast infill wall panels indicated good ductility properties $(5,7,11)$, but, as expected, significantly less strength was attained. The predominance of bending behaviour in three storey infilled frames was observed in contrast to shear dominance that controlled the response of one storey infilled structures.

Using this data, Sugano( ${ }^{(8)}$ proposed the following guidelines with respect to the strength of infill panels with dowel connections:

When the required strength of a strengthened structure is more than $60 \%$ of that obtainable with an identical monolithic wall, $Q_{w}$, or more than $0.6 \sqrt{f_{C}^{\prime}} \mathrm{MPa}$, in terms of concrete shear stress, dowels should be designed to possess a shear stress equivalent to $1.0 \mathrm{MPa}$.

(2) Walls without any connection to a boundary frame may develop a strength corresponding to $0.4 \mathrm{Q}_{\mathrm{W}}$ or $0.3 \sqrt{\mathrm{f}_{\mathrm{C}}^{\mathrm{T}}} \mathrm{MPa}$.

(3) Walls connected to beams but not to columns could be expected to develop strength up to $0.6 \mathrm{Q}_{\mathrm{W}}$ or $0.6 \sqrt{\mathrm{f}_{\mathrm{C}}^{\mathrm{T}}} \mathrm{MPa}$ in terms of shear stress.

\subsection{Braced Frames}

Available data on the response of braced frames is as yet limited. $\mathrm{X}, \mathrm{K}$ and diamond shaped bracing systems were studied. These indicated moderate increases in strength but adequate ductility and ability to dissipate energy. The studies indicated that connection details require careful attention as they might strongly influence the overall hysteretic response.

\subsection{Wing Wall Construction}

The effect of small walls placed adjacent to existing columns or placed separately in the frames was also studied $(5$ $6)$. Cast in place wall additions provided almost as much strength as identical monolithic construction. The addition of precast units resulted in less strength but it produced more ductility.

\subsection{Reinforced Columns}

The types of strengthening techniques shown in Fig. 3 were examined $(5,9)$ experimentally. Both the strength and ductility of poor columns was significantly increased by these strengthening methods. While welded wire fabric wrapping resulted in considerable increase in ductility, the use of steel straps prevented shear failures and delayed the crushing of the concrete.

\subsection{General Effects of Strengthening}

Typical load-displacement relationships for the structures studied are presented in Fig. 7. These are only qualitative indications of the order of strength and ductility that might be attained using different strengthening techniques. The lateral (shear) force, required to develop the full strength of a monolithic reinforced concrete wall with boundary elements, is denoted as $Q_{w}$, while that of the original frame or a column is given as $Q_{F}$ and $Q_{C}$ respectively. It is seen that, when adequate shear connectors are provided, frames 
strengthened by infilled wall panels can develop strength of the order of $0.6 \mathrm{Q}_{\mathrm{W}}$ or $3.5 Q_{F}$ respectively. Steel braces and multiple precast concrete panels without shear connectors gave less strength increase but resulted in improved ductility. Wing walls attached to columns have approximately doubled the strength of the original column while giving considerably increased ductility.

Fig. 8 shows the dramatic improvement attained by strengthening of a column using welded wire fabric wrapping and mortar. Fig. 8 (a) shows the brittle failure of this type of short column that has been extensively used in Japanese construction. Displacement ductilities larger than 6 could be attained with the strengthening technique employed.

Fig. 9 compares the observed response of strengthened three storey and one storey frames. As stated earlier because of the dominance of bending effects, the three storey frames exhibited larger ductility, while the one storey frames suffered brittle shear failures.

\section{STRENGTHENING OF EXISTING BUILDINGS}

More than ten reinforced concrete buildings suffered very severe damage during the 1978, June 12th, Miyagiken-oki Earthquake $(M=7.4)$ in and around the city of Sendai. An earlier earthquake on $\mathrm{Feb}-$ ruary 20 of the same year $(M=6.5)$ also damaged several buildings in Northern Japan. Although some of these buildings were demolished and subsequently rebuilt, many were repaired and also strengthened.

Different techniques were used in these undertakings. Unfortunately no detailed evidence is available, however, to enable a reliable survey to be made. In most cases cast in place reinforced concrete walls with dowel or chipped shear key connections to existing structures were used for strengthening $(2)$. In some cases details similar to those given in Fig. 6 and Fig. $3(\mathrm{~g})$ were used, but exact details are not available.

Some examples of strengthening of both, damaged and undamaged buildings, are briefly described in the following.

\subsection{Damaged School Building "A" (18)}

A five storey college building, shown in Fig. 10, and Fig. 14 (a) to (d) suffered severe damage during the June 1978 earthquake. Particularly "captive columns", such as seen in Fig. $14(\mathrm{~b})$, were affected. Severely damaged columns were replaced with new concrete and additional reinforcement has also been provided. Overall strength with respect to lateral loadings was increased by the addition of infilled walls and also by the thickening of existing walls. In the long direction of the building, cross bracing was added to the framing, as seen in Fig. 14(c) and (d). Bracing members were connected at every floor to existing exterior beams by means of steel plates.

An experimental study was also undertaken to investigate the behaviour of these

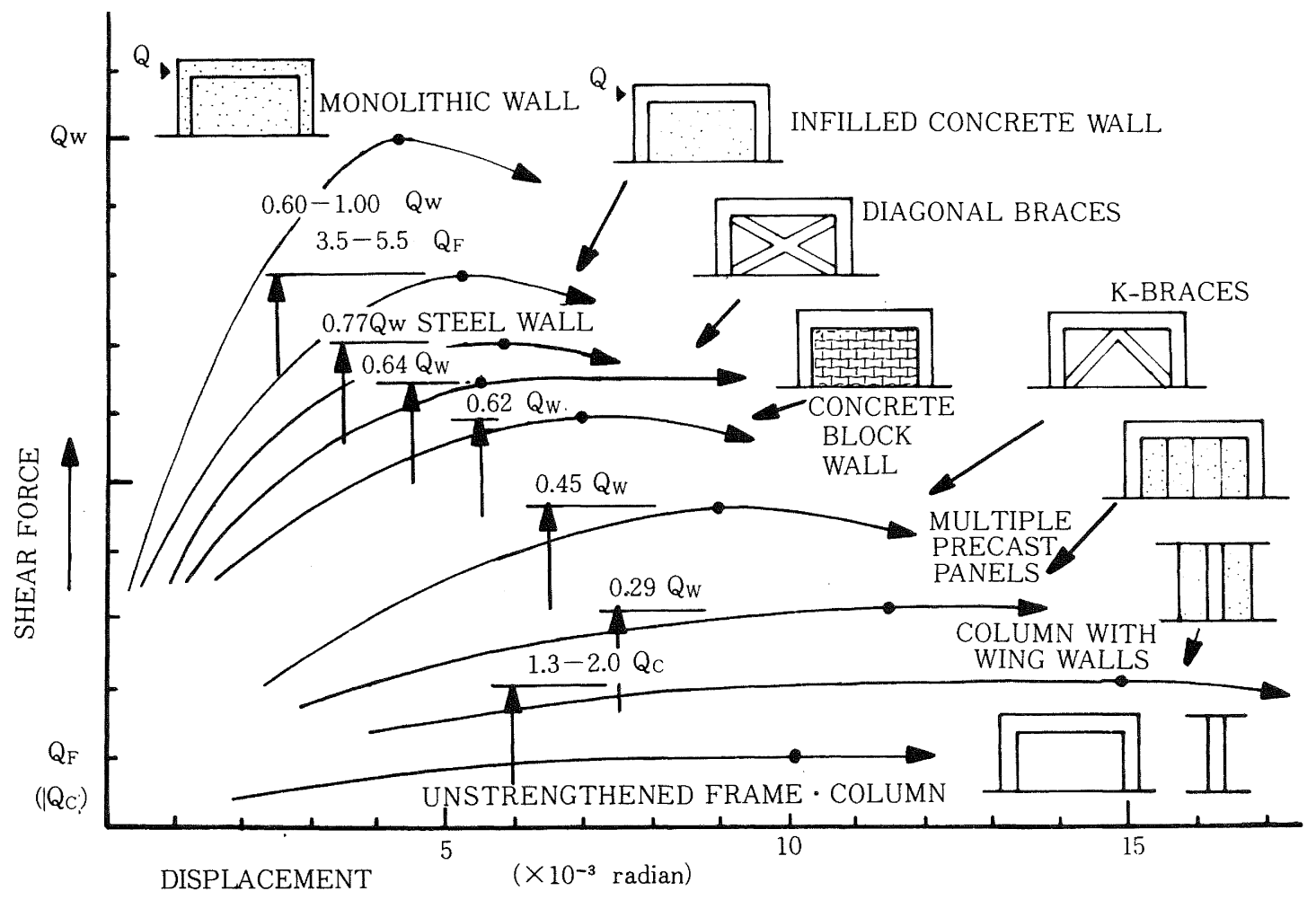




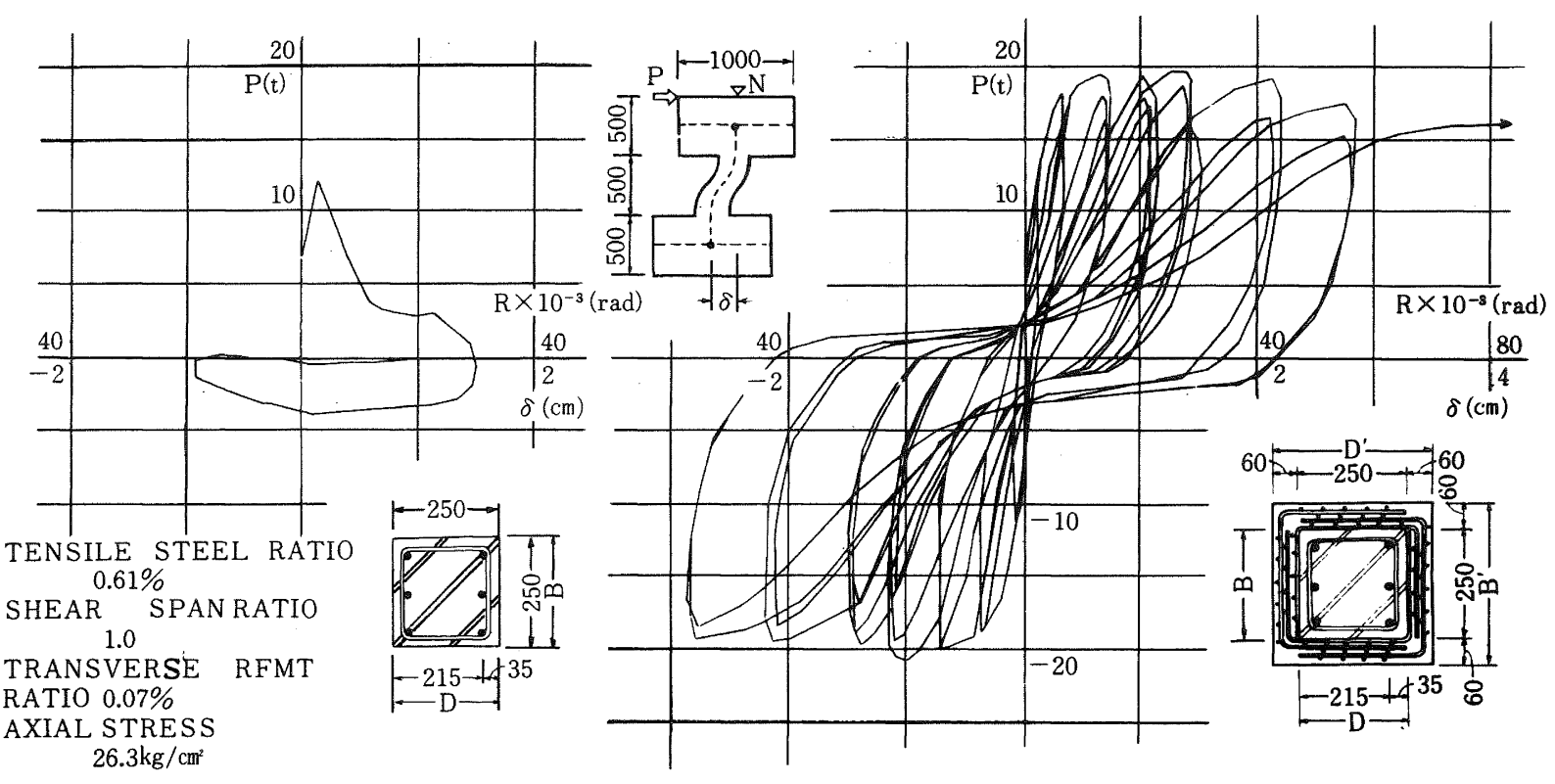

(a) UNSTRENGTHENED

(b) STRENGTHENED BY ADDITIONAL MORTAR AND WRT.DED WTRE FABRICS

FIG. 8 - STRENGTHENING OF COLUMNS

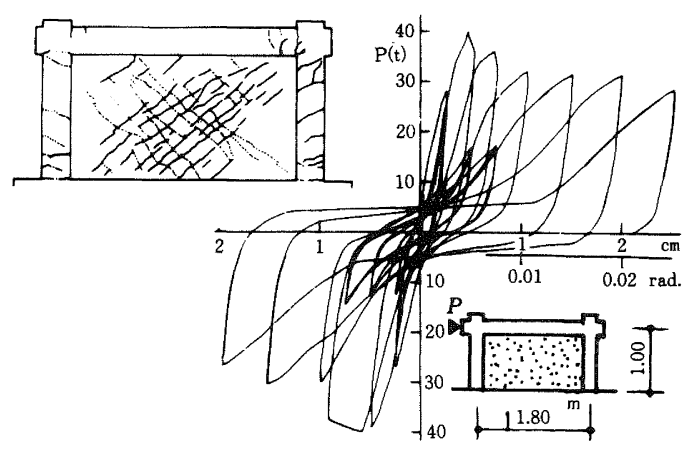

(a) ONE-STOREY INFILLED CONCRETE WALL

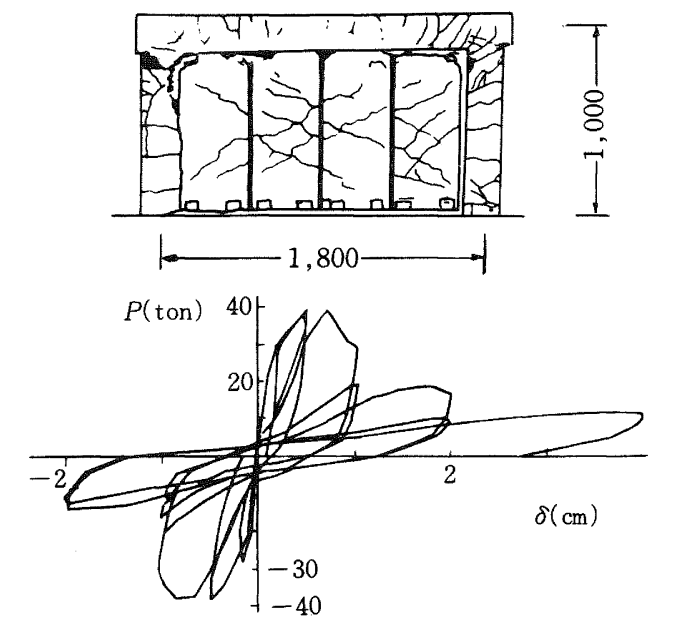

(c) ONE-STOREY MULTIPLE PRECAST CONCRETE PANELS
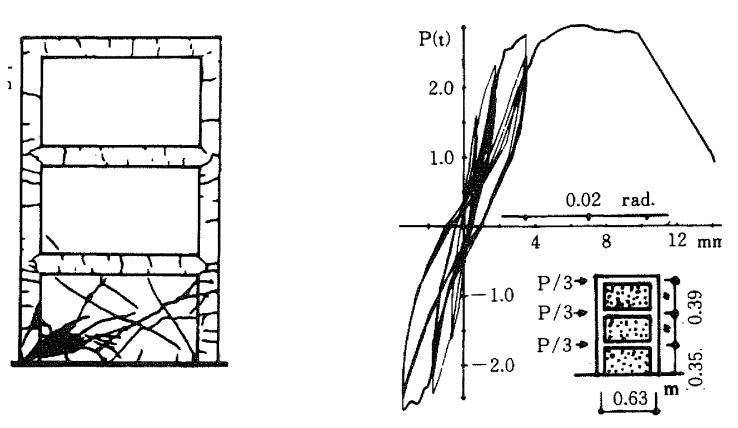

(b) THREE-STOREY INFILLED CONCRETE WALL
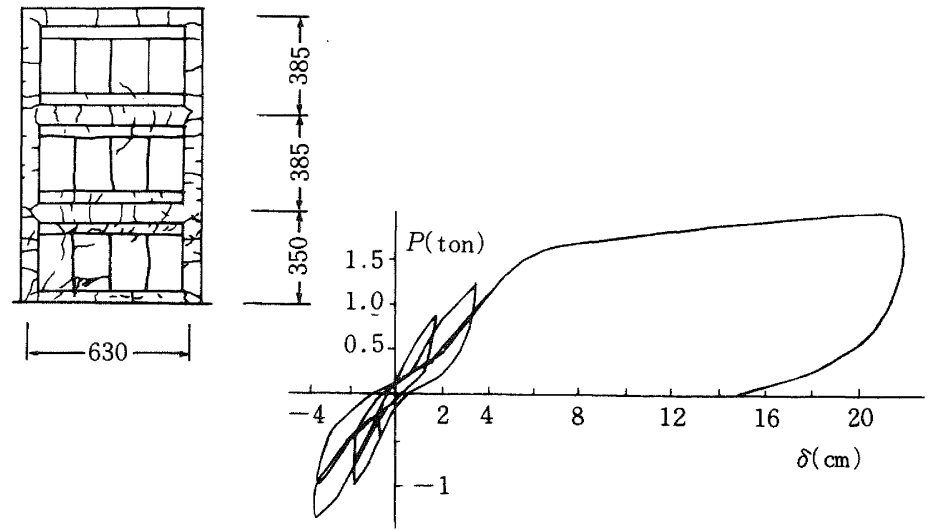

(d) THREE-STOREY MULTIPLE PRECAST CONCRETE PANELS 


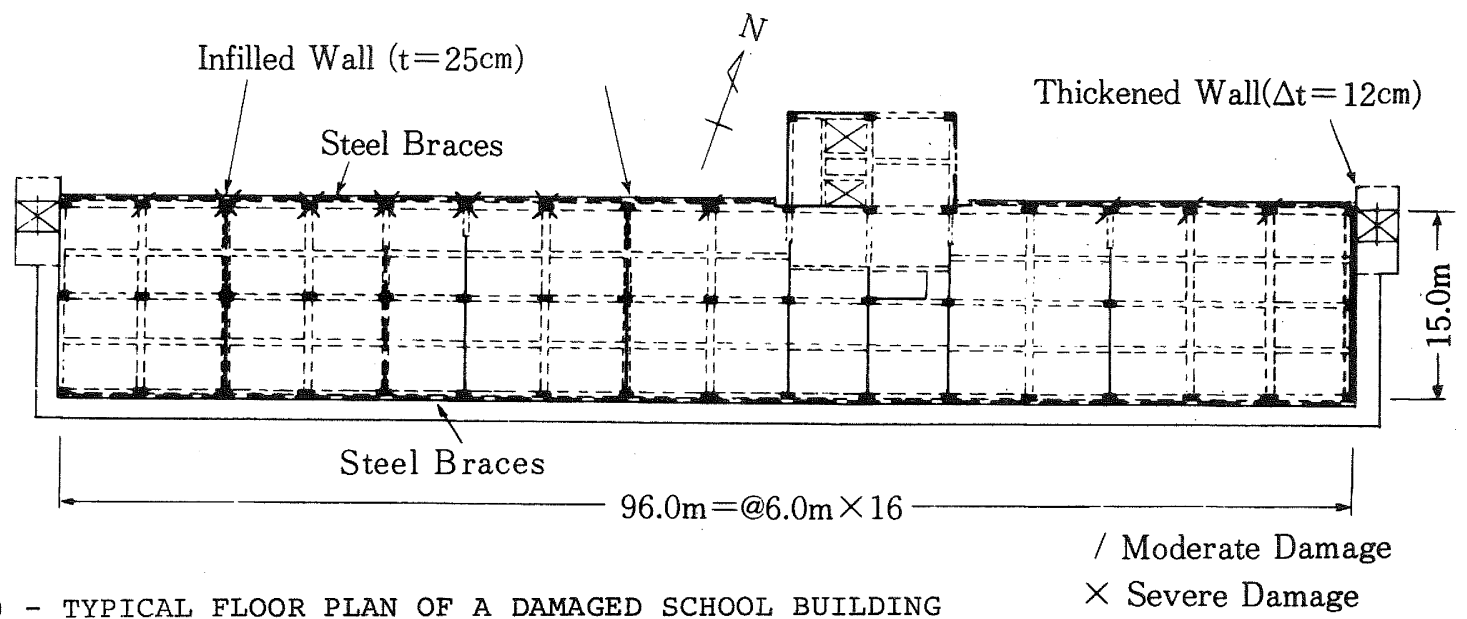

FIG. 10 - TYPICAL FLOOR PLAN OF A DAMAGED SCHOOL BUILDING

Construction for repair and strengthening was under way when the June 1978 earthquake struck. (Fig. 14(i)). The damage during this earthquake was only minor even though the ground shaking in the area was presumably much more intense than during the February event. It appears that the new walls installed, shown in Fig. 12 (b),

TABLE 3 - COMPARISON OF LATERAL FORCE CAPACITY times the strength before the earthquake. Strength increases for each storey are given in Table 3 .

\subsection{Damaged School Building "B" (19)}

During the June 1978 earthquake three buildings of this school suffered moderate to severe damage, as shown in Fig. 11 and Fig. $14(e)$ and (f). Again "captive columns" at the North side were affected mainly by seismic actions in the East-West direction. Severely damaged columns were replaced as in the other School building, while those with lesser damage were repaired with epoxy or the spalled concrete cover was replaced. Major strengthening was achieved by adding concrete walls to the longitudinal frames in the North, to resist East-West seismic actions. Every second bay in the first storey and every fourth bay in the upper storeys, was infilled as seen in Fig. 14(f). Epoxied dowels were used to connect new walls to existing frame members. This resulted in approximately doubling the lateral load resistance of the school blocks in the long direction.

\subsection{Damaged City Hall (15)}

This simple two storey structure, shown in Fig. 12, suffered moderate to severe damage during the earlier February 1978 earthquake. Details of the damage are recorded in Fig. 12 (a) and overall views can be seen in Figs. $14(\mathrm{~g})$ and $(\mathrm{h})$.

TABLE 2 - OBSERVED FUNDAMENTAL PERIODS

\begin{tabular}{|l|c|c|c|c|c|}
\hline & \multicolumn{6}{|c|}{$\begin{array}{c}\text { Coefficient of Lateral } \\
\text { Load Carrying } \\
\text { Capacities }\end{array}$} \\
\hline Storey & 5 & 4 & 3 & 2 & 1 \\
\hline Before earthquake & 0.83 & 0.52 & 0.44 & 0.40 & 0.37 \\
\hline After bracing & 1.19 & 0.99 & 0.93 & 0.83 & 0.66 \\
\hline
\end{tabular}

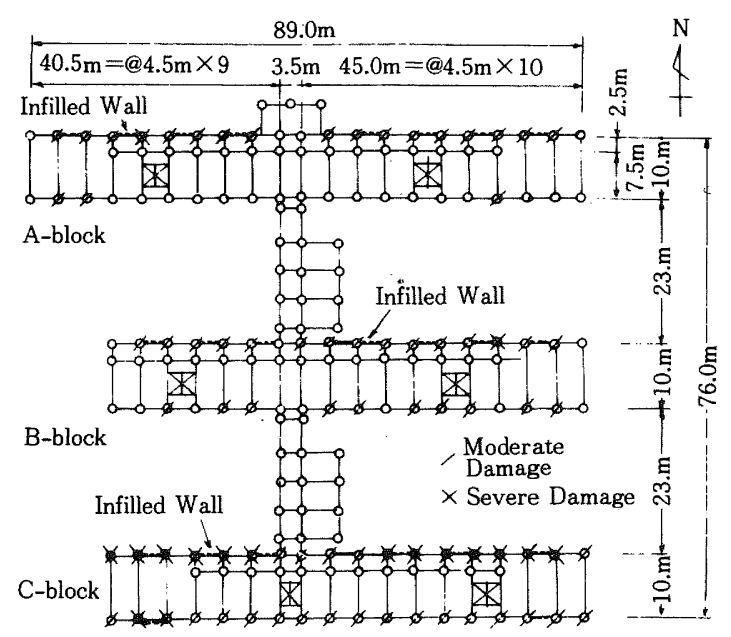

FIG. 11 - STRENGTHENING OF THE DAMAGED SCHOOL BUILDING (I) DUE TO MIYAGIKEN-OKI EARTHQUAKE OF JUNE, $1978(6,7)$

\begin{tabular}{|l|c|c|}
\hline Date of observation & $\begin{array}{c}\text { Transverse } \\
\text { direction }\end{array}$ & $\begin{array}{c}\text { Longitudinal } \\
\text { direction }\end{array}$ \\
\hline April, 1975 & $0.39 \mathrm{sec}$. & $0.34 \mathrm{sec}$. \\
February 22, 1978; after an earthquake of scale IV & $0.39 \mathrm{sec}$. & $0.44 \mathrm{sec}$. \\
June 28, 1978; after the Miyagiken-oki earthquake & $0.43 \mathrm{sec}$. & $0.53 \mathrm{sec}$ \\
February 13, 1979; after restoration of columns & $0.36 \mathrm{sec}$. & $0.49 \mathrm{sec}$. \\
April, 1979 ; after installation of braces & $0.36 \mathrm{sec}$. & 0.35 sec. \\
\hline
\end{tabular}


contributed significantly to the increased strength of the building. This is one of the very few structures in which the effects of strengthening were put to test by a new earthquake. The minor damage experienced give considerable encouragement for further application of this technique.

\subsection{Undamaged Buildings}

'Two four storey school buildings, shown in Fig. 13, were strengthened in the longitudinal direction by infilled concrete walls, which may be seen in both, plans and elevations. Subsequent forced vibration tests indicated some $25 \%$ increase in frequencies in comparison with those measured before the strengthening. This is shown in Fig. 15.

Both, elastic analysis and the seismic evaluation procedure (13), predicted that there would be local damage to columns in the three storey city hall buildings shown in Fig. 16. This was to be expected because of torsional effects. Because of the considerably lower stiffness of the upper storeys, the penthouse was expected to overturn. Additional walls, shown in Fig. 16, were constructed to improve the

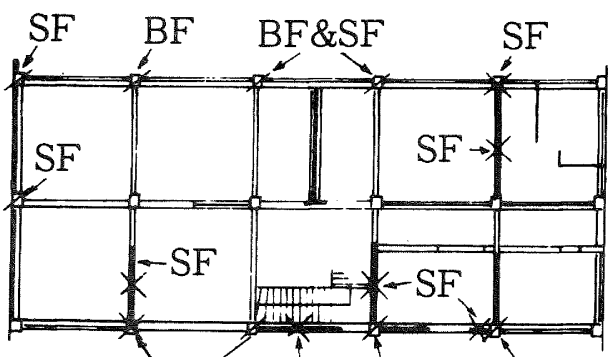

$\mathrm{BF} \& \mathrm{SF} \quad \mathrm{SF} \quad \mathrm{BF} \& \mathrm{SF} \quad \mathrm{SF}$

$\mathrm{BF}$; Bending Failure

SF; Shear Failure
(a) FLOOR PLAN AND
/ Moderate Damage DAMAGE TO MEMBERS
$\times$ Severe Damage (FEBRUARY 1978)

(C)

(B)

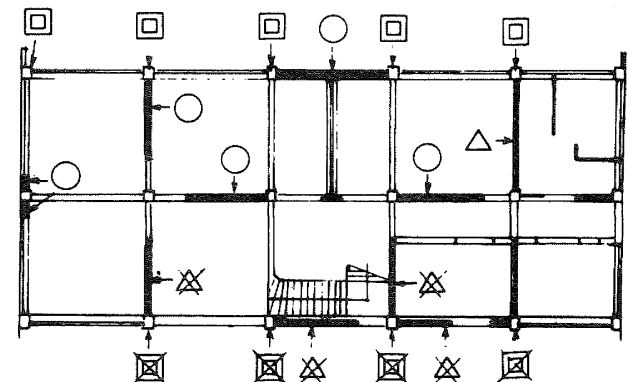
(1)
(2)
(3)
(4)
(5) (6)
OInfilled Wall
$\triangle$ Replaced Wall
回Replaced Column
$X$ before Constrution
(b) CONSTRUCTION FOR REPAIR AND STRENGTHENING (JUNE 1978)

FIG. 12 - STRENGTHENING OF THE DAMAGED CITY HALL modes of vibration and to rectify the eccentricity of stiffness.

\section{CONCLUSTONS}

Because of lack of data, insufficient experience with and understanding of seismic phenomena, a great deal of work is yet to be done in the area of strengthening of reinforced concrete buildings. Some of the problems to be solved before improved guidelines for seismic strengthening can be compiled, are as follows:

(1) Analytical and experimental approaches should be used to assess the effect of strengthening on the overall seismic behaviour of buildings. Further experimental verification of the behaviour of strengthened subassemblages is required. Workmanship and the detailing of connections greatly affects the response of strengthened structures. These aspects are difficult to model and for this reason it is desirable to test large if not full scale specimens.

(2) Existing test data must be evaluated more systematically to obtain reliable global information with respect to energy dissipation capacity, displacement capacity, stiffness deterioration and potential strength to resist earthquake forces.
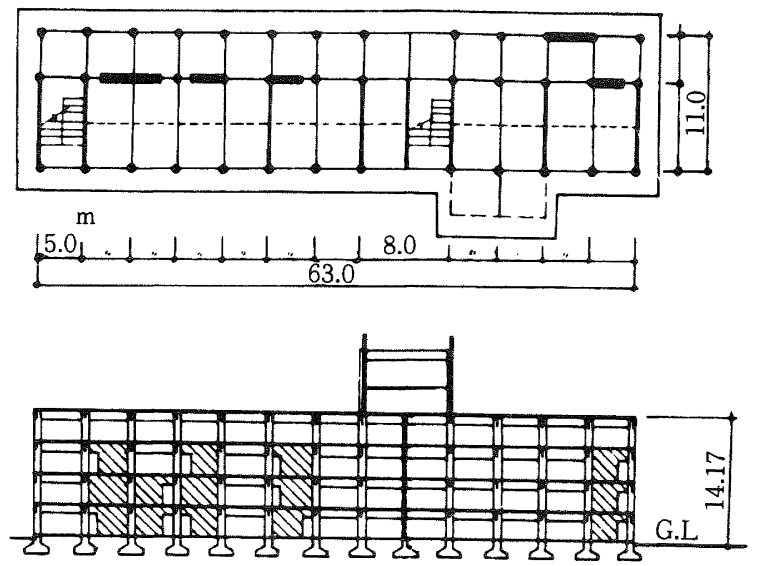

(a) SCHOOL BUILDING A
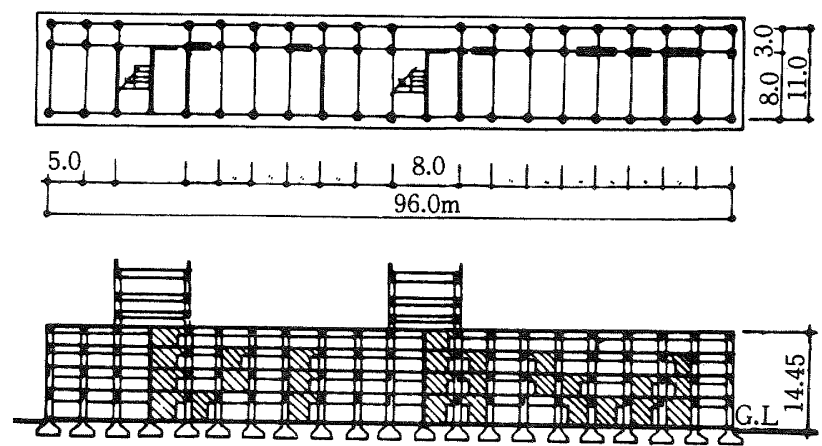

(b) SCHOOL BUILDING B

FIG. 13 - STRENGTHENING OF UNDAMAGED SCHOOL BUILDINGS 


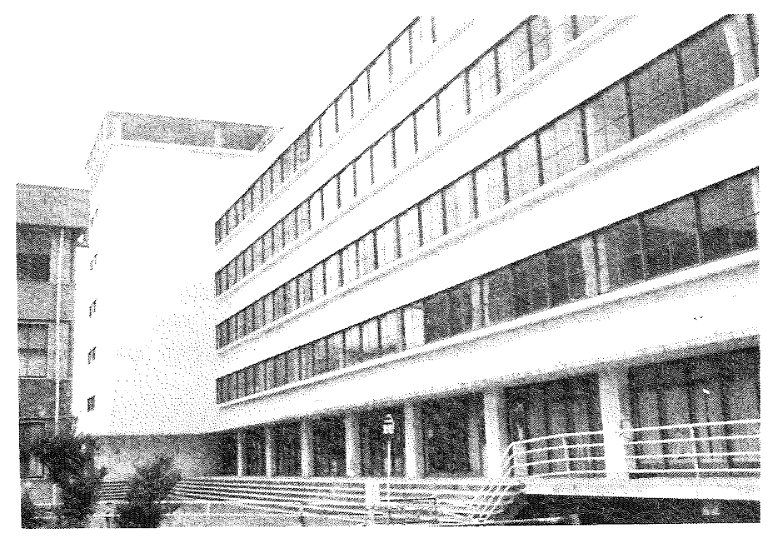

(a)

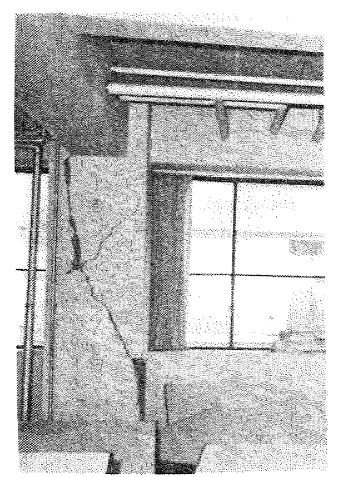

(b)

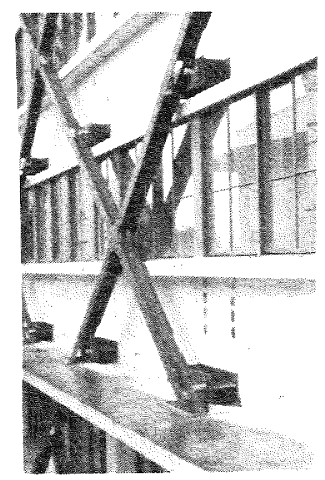

(c)

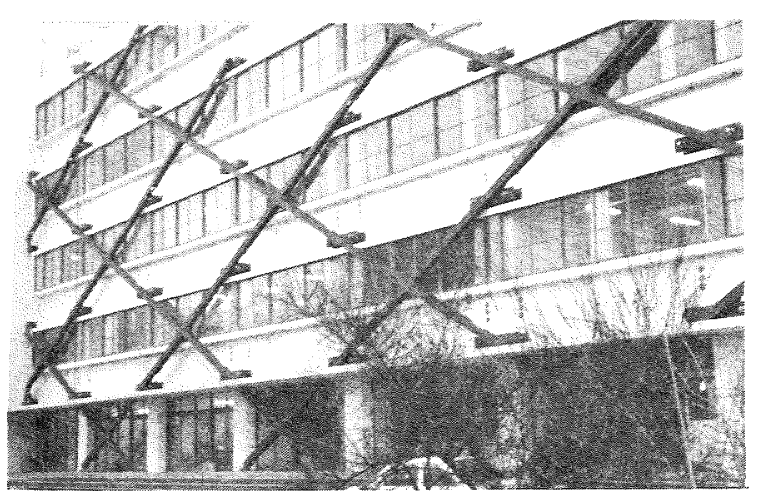

(d)

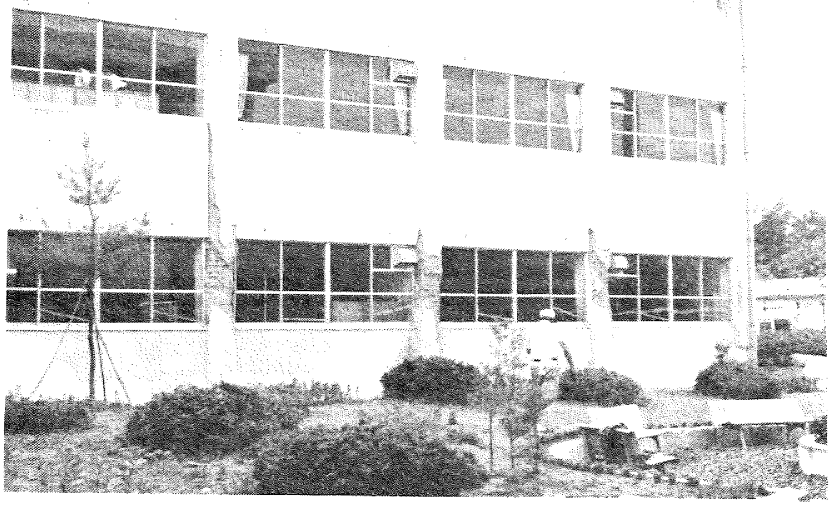

(e)

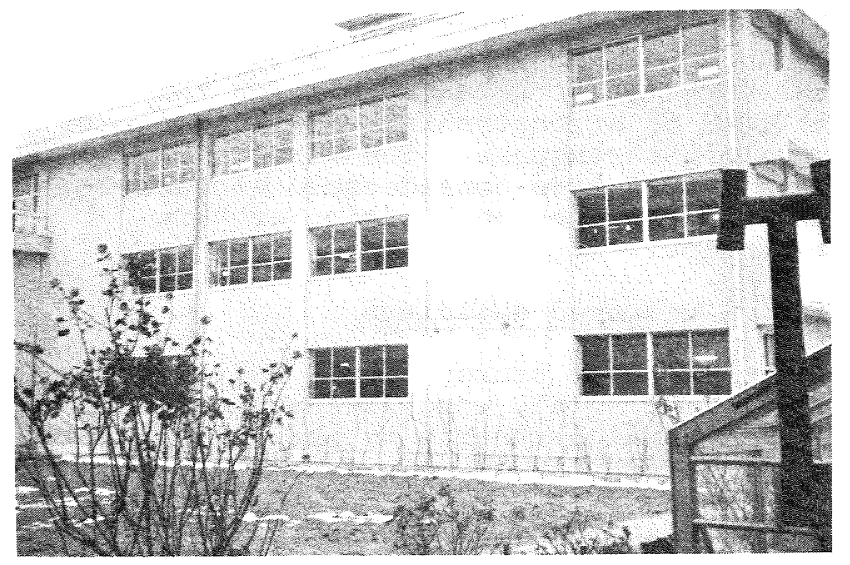

(f)

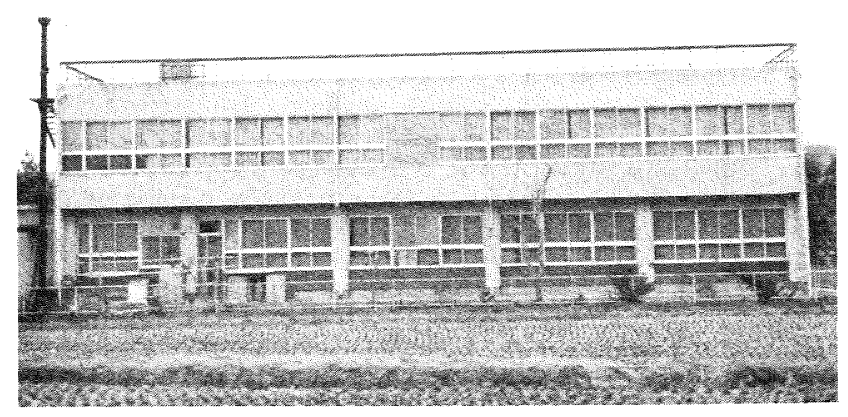

(g)

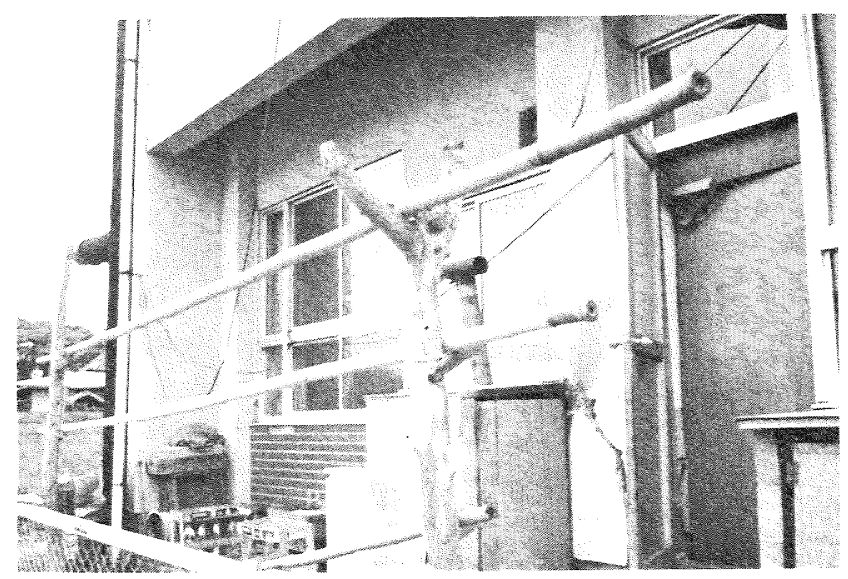

(h)

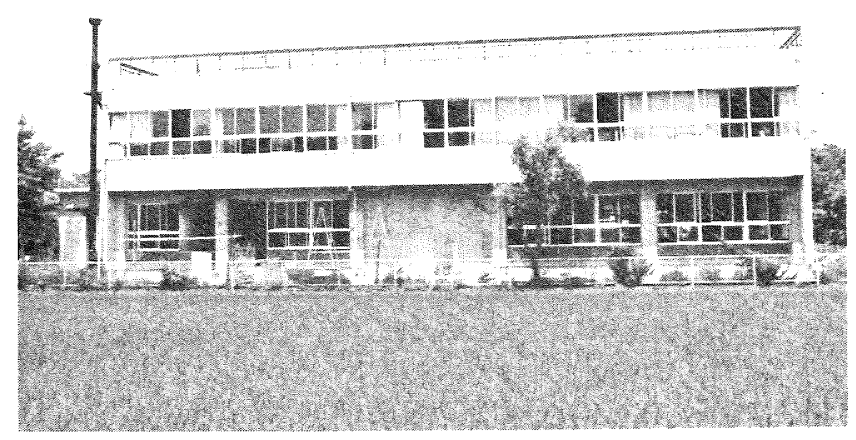

(i) 


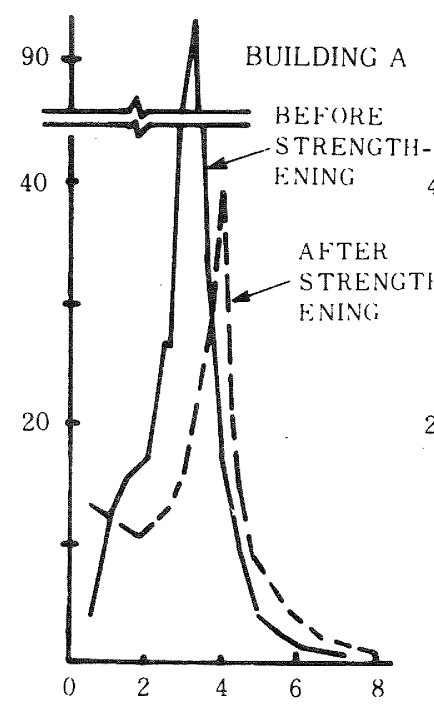

FREQUENCY (HZ)
BUILDING B

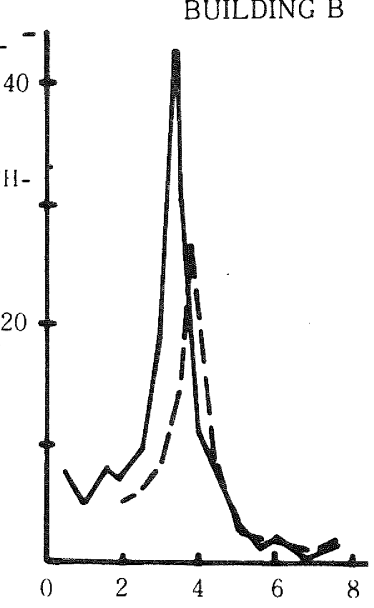

FREQUENCY (HZ)

FIG. 15 - RESONANCE CURVES OBTAINED BY FORCED VIBRATION TESTS

(3) Additional information is required with respect to infilling techniques, the use of precast and bracing elements and methods of connections to existing structural systems.

(4) It is desirable that data for design and construction for seismic strengthening be integrated and compiled for the benefit of potential users. Engineering approach to strengthening

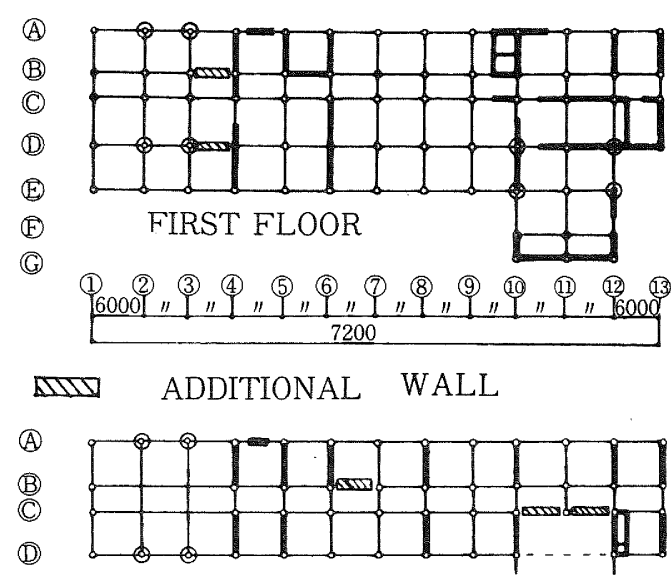

THRD FLOOR

(a) PLAN
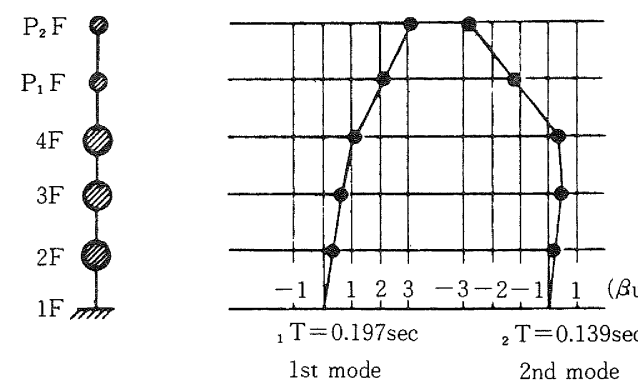

a) UNSTRENGTHENED

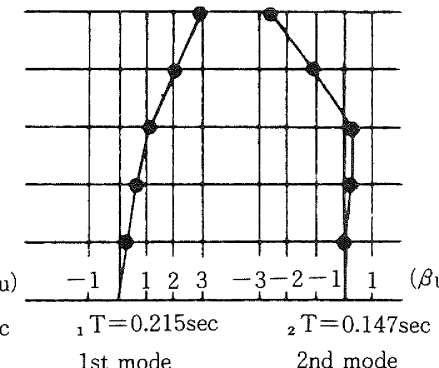

b) AFTER EXTENSION

AT 4TH FLOOR

will still have to rely on experience so gained and on judgement.

\section{ACKNOWLEDGEMENTS}

This paper is a slightly modified version of that previously published (20). It was prepared in response to an invitation from the New Zealand National Society for Earthquake Engineering. For this reason a great many of the references, published in Japanese, have been omitted. The report, however relied strongly on the work of others, and therefore the author wishes to acknowledge the invaluable contribution of other Japanese researchers, especially those of Hiroshi Imai, Minoru Kondo, Masayoshi Yokoyama, Shigeya Kawamata, Jiro Suzutani, Masaaki Ohnuma, Masami Miyazawa, Junichi Onose, Yoshihiro Abe, Masaya Hirosawa, Seiji Kokusho, Ikuo Yamaguchi, Masaru Fujimura, Toneo Endo, Takashi Arakawa, Norimasa Tsunoda, Yoichi Higashi, Tsuneo Okada, Chiyokazu Yamada and Takehiko Kato.

The editorial assistance extended in New Zealand by Professor T. Paulay is also acknowledged.

\section{REFERENCES}

(1) Masaya Hirosawa and Tetsuya Goto, "Rehabilitation of Damaged Buildings due to 1968 Tokachi-oki Earthquake", Concrete Journal, August, 1969, Japan Concrete Institute.

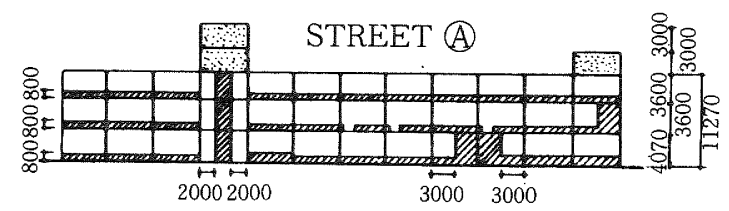

ADDITIONAL WALL

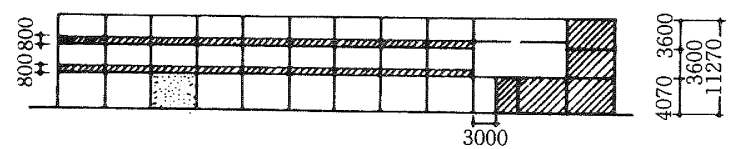

(b) SECTION

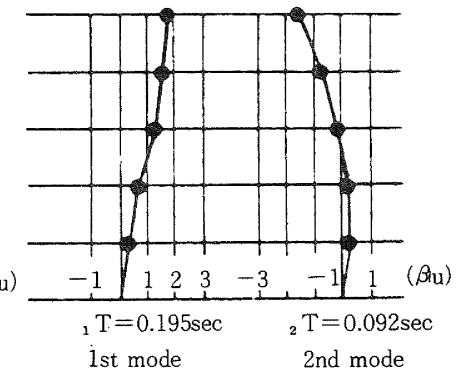

c) AFTER EXTENSION AT 4TH FLOOR AND STRENGTHENING

(C) CALCULATED ELASTIC VIBRATION MODES 
(2) Masaya Hirosawa and Kaname Tatahara "Design Guidelines for Seismic Retroffiting of Reinforced Concrete Buildings", Journal of Building Disaster Prevention, October, 1979, The Japan Building Disaster Prevention Association.

(3) Robert D. Hanson, "Repair and Strengthening of Reinforced Concrete Members and Buildings", Proceedings of Workshop on Earthquake Resistant Reinforced Concrete Building Construction (ERCBC), University of California, Berkeley, July, 1977.

(4) Robert D. Hanson, "Repair, Strengthening and Rehabilitation of Buildings - Recommendations for Needed Research", University of Michigan, UMEE 77R4, October 1977.

(5) Yoichi Higashi and Seiji Kokusho, "The Strengthening Method of Existing Reinforced Concrete Buildings", Proceedings of the Review Meeting of US-Japan Cooperative Program in Earthquake Engineering with Emphasis on the Safety of School Buildings, Honolulu, Hawaii, August 1975.

(6) Yoichi Higashi, Masamichi okubo and Kou Fujimata, "Behaviour of Reinforced Concrete Columns and Frames Strengthened by Adding Precast Concrete Walls", 6 WCEE, New Delhi, 1977.

(7) Yoichi Higashi, et al, "Experimental Study of Strengthening Reinforced Concrete Structures by Adding Shear Wall", 7 WCEE, Istanbul, Turkey, 1980.

(8) Shunsuke Sugano and Masaru Fujimura "Aseismic Strengthening of Existing Reinforced Concrete Buildings", 7 WCEE, Istanbul, Turkey, 1980 .

(9) Tetsuya Sasaki, et al, "An Experimental Study on Earthquake Resistant Strengthening Work for Existing Reinforced Concrete Buildings", Proceedings of the Review Meeting of USJapan Cooperative Program in Earthquake Engineering, August 1975.

(10) Lawrence T. Kahn, "Reinforced Concrete Infilled Shear Walls for Aseismic Strengthening", Ph.D. Thesis, University of Michigan, Ann Arbor, Michigan, 1976 .

(11) Lawrence F. Kahn and Robert D. Hanson, "Reinforced Concrete Shear Walls for Aseismic Strengthening", 6 WCEE, New Delhi, 1977.

(12) "Design Guidelines for Aseismic Retrofitting of Existing Reinforced Concrete Buildings", The Japan Building Disaster Prevention Association, March, 1977.

(13) Hiroyuki, Aoyama, "Outline of Earthquake Provisions in the Recently Revised Japanese Building Code", Bull. of the N.Z. Nat. Soc. for Earthy. Eng., Vol. 14, No. 2, June, 1981.
(14) Ikuo Yamaguchi, Shunsuke Sugano, et al, "An Experimental Study on Aseismic Strengthening of Existing $\mathrm{R} / \mathrm{C}$ LowRise Buildings", Takenaka Technical Research Report, No. 21, April, 1979.

(15) Katsuhiko Saito, Shunsuke Sugano, et al, "The Damage to Buildings Due to Miyagiken-oki Earthquakes of February 20 and June 12, 1978", Takenaka Technical Research Report, No. 21, April, 1979 .

(16) Takatoshi Miki, Takashi Homma and Masaya Hirosawa, "Evaluation of Earthquake Resistant Properties and Strengthening of Existing Buildings", Proceedings of Fifth World Conference on Earthquake Engineering, Rome, Italy Italy, 1973.

(17) Toshio Hayashi, et al, "The Strengthening Methods of the Existing Reinforced Concrete Buildings", 7 WCEE, Istanbul, Turkey, 1980.

(18) Shigeya Kawamata and Masaaki Ohmura, "Strengthening Effect of Eccentric Steel Braces to Existing Reinforced Concrete Frames", 7 WCEE, Istanbul, Turkey, 1980.

(19) M. Yokoyama and H. Imai, "Earthquake Damage at Izumi High School in 1978 Miyagiken-oki Earthquake and Methods of Repair and Strengthening", 7 WCEE, Istanbul, Turkey, 1980.

(20) Shunsuke Sugano, "State-Of-The-Arts in Aseismic Strengthening of Existing Reinforced Concrete Buildings in Japan", Takenaka Technical Research Report, No. 25, April, 1981. 